\title{
ANALYSIS OF NEW TYPE AL-SI-MG ALLOY STRUCTURES WITH DIFFERENT CONTENTS OF CA DUE TO CHEMICAL PROPERTIES
}

\author{
Elena Strihavkova \\ J.E.Purkyně University in Ústí nad Labem \\ strihavkova@fvtm.ujep.cz
}

\begin{abstract}
The area of use of aluminum and aluminum alloys is very wide and the future use of aluminum alloys is related to the further development of new alloys, but primarily with the production technology and processing. Recently addition master alloy AlCa10 is used with aluminum alloy for improving the technological properties. The aim of the article is analysis and comparation of the new type $\mathrm{Al}-\mathrm{Si}-\mathrm{Mg}$ alloy with different contents of calcium, from the minimum content of the $0.1 \% \mathrm{Ca}$, to the maximum content of the $1 \% \mathrm{Ca}$ and to find the optimum quantity to achieve the required properties. The analysis was performed by the alloy $\mathrm{AlSi} 7 \mathrm{Mg} 0.3$ alloyed with master alloy AlCa10. The newly prepared alloys were analysed by the structural analysis with emphasis on research in the chemical properties - resistance to corrosion. The sample metallographic grindings were prepared for the study of the structures by means of color contrasts in order to determine the changes in corrosion behavior.
\end{abstract}

Keywords: aluminum alloy $\mathrm{AlSi} 7 \mathrm{Mg} 0.3$, addition master alloy $\mathrm{AlCa} 10$, structural analysis, chemical properties, corrosion resistance.

\section{Introduction}

Aluminum alloy AlSi7Mg0.3 is foundry alloy, which is the basic element of aluminum (Al) what means that it constitutes more than $50 \%$ of the content of the alloy. The second most important element is silicon $(\mathrm{Si})$. Magnesium $(\mathrm{Mg})$ is the next additive element. The alloy $\mathrm{Al}-\mathrm{Si}-\mathrm{Mg}$ is among hardenable silumins where hardened by the secured elimination phase of $\mathrm{Mg}_{2} \mathrm{Si}$. This alloy has a wide and current range of application in the aerospace industry, for castings of wheels for cars and not least for the motor parts. One of the most effective options to a significant increase of the mechanical properties is vaccination and modification of alloy. From the point of view of properties it is an alloy with high strength, after the modification the strength values reach above $300 \mathrm{MPa}$. The alloy is characterized by very good resistance to corrosion, resistance to fresh and salt water and good foundry properties [1].

The contribution deals with the influence of the added master alloys AlCa10 hypoeutectic silumin AlSi7Mg0.3, mainly due to the chemical properties of the new alloy AlSi7Mg0.3Ca. Modifying is the process by which liquid alloy is treated with different elements, or their alloys, in order to influence the mechanism of the solidification of the eutectic. Calcium causes in the original alloy AlSi7Mg0.3 a distinct change in the structure, and that the exclusion of the eutectic silicon in the form of sticks until the fibers in the plane of the metallographic cut appear as rounded grains, further has an effect on the already mentioned corrosion resistance.

From the binary diagram Al-Ca (Fig. 1) it is readable, the solubility of calcium in the aluminum to a certain extent, that it is a hypereutectic alloy. Alloy AlCa10 contains eutectic $(\alpha+\mathrm{AlCa} 4)$ and coarse plates CaAl4 phase [6]. In the structure also metallurgical defects are apparent and large pores. It can also be said that the material master alloy $\mathrm{AlCa} 10$ has a considerable degree of the structural heterogeneity, and that in the distribution boards CaAl4 phase.

The modification effect of calcium is not yet fully explored. Opinions on the modification of AlSi calcium essentially diverge. Part of the authors consider calcium in modifier, as we can read in [3], the second part just because calcium has a certain modification effect, it is considered an element of threat, the structure of the modified calcium is of inferior quality as in the case of solidification sodium. The effectiveness of the modification effect is longer. During slow solidification the lamellar structure of the eutectic forms with the attendant typical shrinkage that cannot be eliminated even using the bosses. The presence of calcium as impurities (approximately from $0.1 \mathrm{um}$. \%) in the alloys $\mathrm{Al}-\mathrm{Si}$ is manifested as an improved oxidation result in porosity and microcavity. 


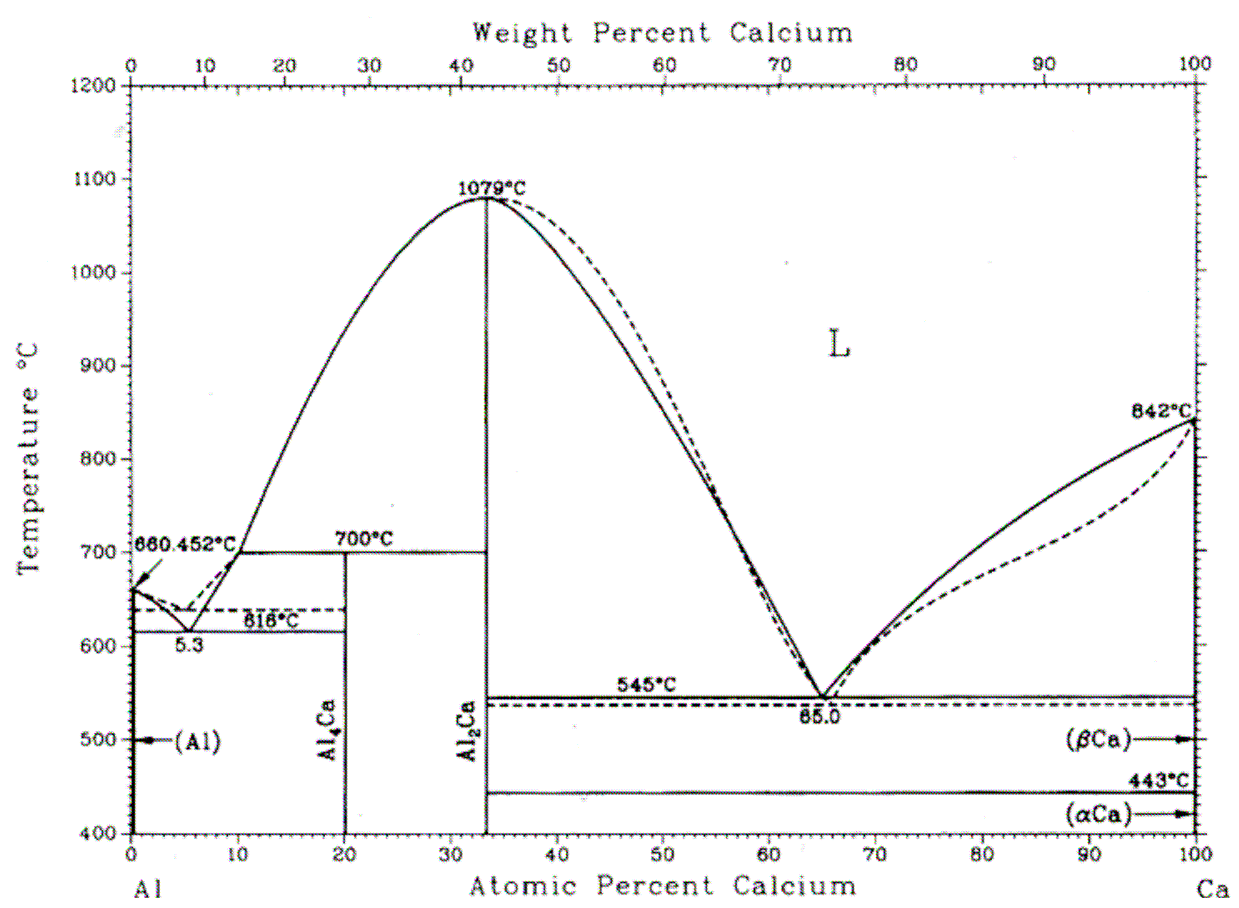

Fig. 1. Binary diagram of aluminium - calcium [6]

\section{Preparation of melts of alloy AISi78Mg0.3 with different content of $\mathrm{Ca}$}

For experimental purposes hypoeutectic silumin AlSi7Mg0.3 was used with the input chemical composition listed in Table 1. Alloying was done using calcium in the form of master alloys AlCa10. Total there were 4 casts, the first without the addition of calcium and the others with a graded amount of calcium $0.1 \%, 0.5 \%$ and $1 \%$. The various operations of melting, refining and alloying are carried out in a furnace at a temperature of $720^{\circ} \mathrm{C}$. In every melting process the melt was treated with refining of salts and from the surface of the melt smear was withdrawn. The melt was cast by gravitation into a metal mold preheated to a temperature of $220^{\circ} \mathrm{C}$.

Table 1

Entrance chemical composition of alloys AlSi7Mg0.3

\begin{tabular}{|c|c|c|c|c|c|c|c|c|c|}
\hline \multirow{2}{*}{ Alloy } & \multicolumn{8}{c|}{ Chemical composition in the hm. \% } \\
\cline { 2 - 10 } & $\mathrm{Si}$ & $\mathrm{Fe}$ & $\mathrm{Cu}$ & $\mathrm{Mn}$ & $\mathrm{Mg}$ & $\mathrm{Cr}$ & $\mathrm{Ni}$ & $\mathrm{Zn}$ & $\mathrm{Ti}$ \\
\hline AlSi7Mg0.3 & 7.09 & 0.105 & 0.001 & 0.017 & 0.230 & 0.001 & 0.001 & 0.003 & 0.118 \\
\hline \multirow{2}{*}{ Alloy } & \multicolumn{8}{|c|}{ Chemical composition in the hm.\% } \\
\cline { 2 - 11 } & $\mathrm{B}$ & $\mathrm{Be}$ & $\mathrm{Ca}$ & $\mathrm{Cd}$ & $\mathrm{Ga}$ & $\mathrm{Li}$ & $\mathrm{Na}$ & $\mathrm{V}$ & $\mathrm{Al}$ \\
\hline AlSi7Mg0.3 & $<0.0001$ & $<0.0000$ & $<0.0002$ & 0.0036 & 0.0131 & $<0.0000$ & 0.0004 & 0.0031 & $<92.41$ \\
\hline
\end{tabular}

\section{Test of corrosion resistance}

It is one of the important chemical properties of corrosion resistance. Generally, high purity metal has the highest corrosion resistance. Ingredients in technically pure aluminum reduce its corrosion resistance, because with the exception of $\mathrm{Mn}$ they are all against the $\mathrm{Al}$ cathode. The influence of impurities on the corrosion properties of aluminum depends on the applied electrolyte, whether they are present in solid solution or in the form of heterogeneous particles. The basic corrosion properties of $\mathrm{Al}$ alloys are given by the criteria of their passive state and the parameters of the critical values of the corrosion process. The corrosion potential is in real conditions different from the standard potential, it is the content and the electrochemical character of an alloying element [1].

The purpose of the test corrosion is to compare the resistance of the alloy to the action of salt mist. The test of salt spray was according to the DIN 50021 (DIN EN ISO 9227). The samples were constantly exposed to salt mist, in conjunction with higher temperature created by reinforced corrosion. In Tab. 2 the conditions under which the test of corrosion resistance was performed are shown. 
Conditions for the test in the corrosion chamber

\begin{tabular}{|c|c|}
\hline Test parameters & Neutral salt mist \\
\hline Temperature & $35 \pm 2{ }^{\circ} \mathrm{C}$ \\
\hline $\begin{array}{c}\text { The average speed of the accumulation of spray } \\
\text { mist from horizontal collecting areas } 80 \mathrm{~cm}^{2}\end{array}$ & $1.5 \pm 0.5 \mathrm{ml} \cdot \mathrm{h}^{-1}$ \\
\hline $\begin{array}{c}\text { The concentration of the solution of sodium } \\
\text { chloride (in accumulated solution) }\end{array}$ & $50 \pm 5 \mathrm{~g} \cdot 1^{-1}$ \\
\hline $\mathrm{pH}$ (in accumulated solution) & 6.5 to 7.2 \\
\hline The time of corrosion load & 720 hours \\
\hline
\end{tabular}

For the test of corrosion resistance the samples cast in graphite crucibles were used. These castings were cut across a band saw. After the distribution of all castings the samples were sanded according to the requirements on the quality of the surface of the specimens for microscopic analysis. Preparation of the samples was realized on a laboratory grinding machine MTH KOMPAKT, which operates in the range of 30-600 rpm. The samples were ground papers with carbides of silicon of a grain size of 180, 400600,800 and 1500 grains per square inch. Always when switching to the next sandpaper the samples were rotated by $90^{\circ}$ and perpendicular to the traces of the previous grinding. The process of grinding was all the time accompanied by a steady stream of flowing water, which prevents the influence of the structure of the samples by the heat, which during grinding is formed and also the water drains the impurities and fine chips are generated in the working space of the grinder. After grinding the samples were rinsed under a stream of running water, under alcohol, and subsequently dried with hot air.

The corrosion resistance test is carried out in an environment that accelerates the corrosion process, and the manner in which there is an amplification of certain influences, such as temperature, relative humidity of the atmosphere and condensation of moisture or condensation corrosive agents. Before inserting the samples in the corrosion chamber the samples were marked, stamped number 1 to 4 according to the content of calcium as in the previous cases, subsequently, the samples were stored in the mist. The test was carried out at a temperature of $35^{\circ} \mathrm{C}$ in salt mist created by the spray of $5 \%$ tion aqueous solution of $\mathrm{NaCl}$ during 30 days ( 720 hours). For the test of corrosion resistance the corrosion chamber LIEBISCH ${ }^{\circledR}$ was used. In the corrosion chamber the samples were placed so as not to touch and affect each other. Also the placement of the samples must be such that each other could not shield against the effects of corrosive environments. After two exposures the samples were excluded from the chamber, by rinsing of them the remains of the corrosive atmosphere were removed and they were subsequently hot air dried.

\section{Microscopic analysis of the samples of the test of corrosion resistance}

After performing the corrosion test the nature and extent of corrosion attack were evaluated first visually and then it was documented using a confocal laser microscope Olympus LEXT OLS 3100 at a magnification of 100x and 200x.

On the basis of visual evaluation it was found that the nature of the surface assault is in all samples of the test alloys 1 to 4 similar. After 720 hours of exposure of the samples in the corrosion chamber on the surface were apparent small local areas of corrosion attack, with the character most similar to uneven corrosion and corrosion pitting. After conducting further analysis revealed that the infestation grows further in depth into the area.

Metallographic evaluation of the laboratory tests was performed in order to more precisely determine the causes of failures caused by corrosion, for determining the type, location and shape of the corrosion attack. An important factor for microscopic analysis is the sample preparation. Material for analysis was taken from the castings from the graphite crucible in the centre section in order to minimize the exposure to the effects of external factors. For separation of the marked areas the crawler PPK 175 and the circular saw Mikron 110 were used. As the jointing compound Dentakryl (Versocit2) was applied to the resin. The processes of grinding and polishing of individual samples were performed on the laboratory horizontal grinding machine KOMPAKT 1031. The used abrasive papers should grit 180, 400, 800 and 1500 abrasive grains per square inch. Polishing emulsion was applied on 
the abrasive cloth, wherein for each emulsion a new special canvas was used appropriate for the given grit polishing emulsion. For achieving the color contrast the samples were etched using potassium permanganate in alkaline environment of hydroxide form for a few seconds.

\section{Default alloy AlSi7Mg0.3 with $0 \% \mathrm{Ca}$}

The first sample was prepared with no added calcium. On the cast sample metallographic analysis was carried out using colour contrast, which is used for visibility of the structures. In Fig. 2 is shown in 100x magnification the displayed starting structure of hypoeutectic non-modified silumin, where it is possible to observe surface pitting corrosion, which further can grow even into the volume on the material. This structure is composed of dendrites of $\alpha$-phase and platelets of eutectic silicon in a solution of $\alpha$ as deployed in between the dendritic areas. In these between the dendritic areas porosity cast was evident in the whole volume of the material, what is the suspected reason for the emergence of surface corrosion attack pitting corrosion. The size of the seats contested corrosive damage ranges from 10 to $25 \mu \mathrm{m}$. In Fig. 3 100x magnification is instead attacked by corrosion, which progresses to a depth of up to several tens of $\mu \mathrm{m}$.

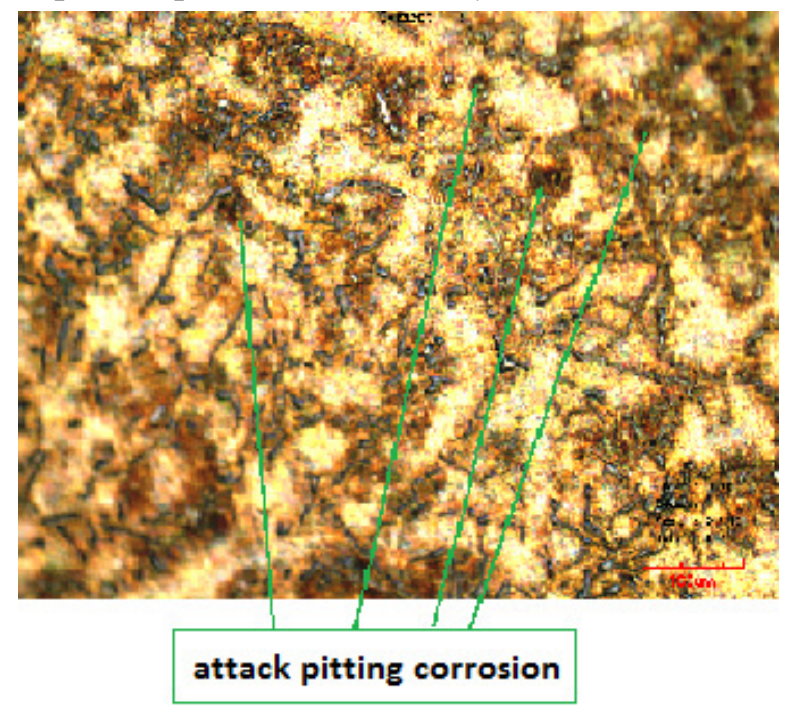

Fig. 2. Microstructure of corrosion attack of alloy AlSi7Mg0.3 with $0 \%$ Ca. The structure is composed of grains of solid solution $\alpha$, eutectic and platelets eutectic silicon. The structure is evident surface pitting corrosion. Colour etching solution $\mathrm{KMnO4+NaOH}$ (100x magnification)

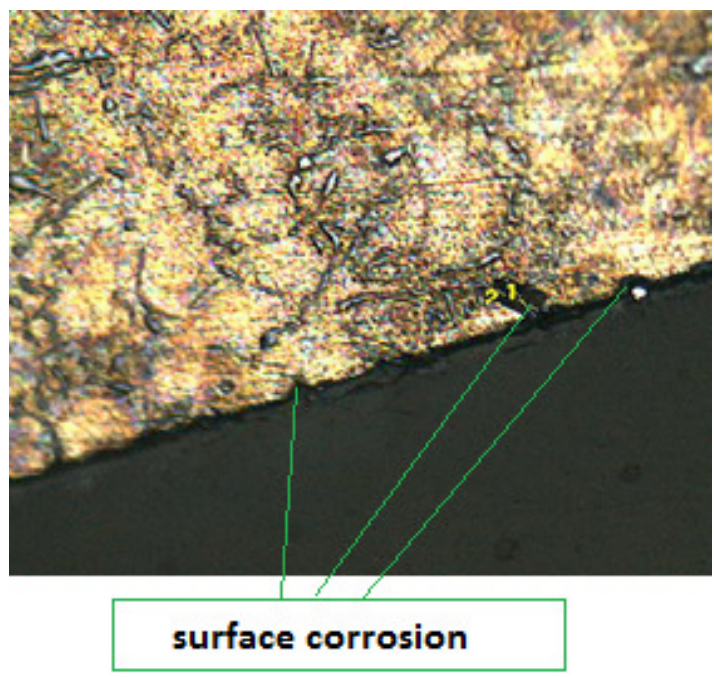

Fig. 3. Microstructure of corrosion attack of alloy AlSi7Mg0.3 with $0 \%$ Ca. The structure is composed of grains of solid solution $\alpha$, eutectic and platelets eutectic silicon. The structure is evident surface corrosion penetrating into the depth of the material with a size of approximately $20 \mu \mathrm{m}$. Colour etching solution $\mathrm{KMnO} 4+\mathrm{NaOH}$ (100x magnification)

\section{Default alloy AlSi7Mg0.3 with $0.1 \%$ Ca}

The second cast was the added calcium in the amount of $0.1 \% \mathrm{Ca}$. Analysis of the microstructure describes the modification effect of calcium on the default structure. This is visible in the following figures, where there is a clear refinement of the microstructure in comparison with the initial alloy, what is manifested by rounded particles of silicon elongated shape. Also porosity appears and the emergence of thickened particles of the eutectic silicon about the size of a few tens of $\mu \mathrm{m}$. It is also possible to observe the curvature of the edges of the needle like formations the gradual transition of the shape of the needles to rounded particles, which metallographic thin section appears in the form of rods and fibres on the difference from the original hexagonal plates. In Fig. 4 is shown the microstructure of the alloy contested area pitting corrosion, the distribution of seats after the corrosive attack is more regular and more pronounced at 100x magnification. In the next picture (Fig. 5) with $100 \mathrm{x}$ magnifications is surface corrosion shown, which in this case progresses in the depth of the material a few tens to hundreds of $\mu \mathrm{m}$. 


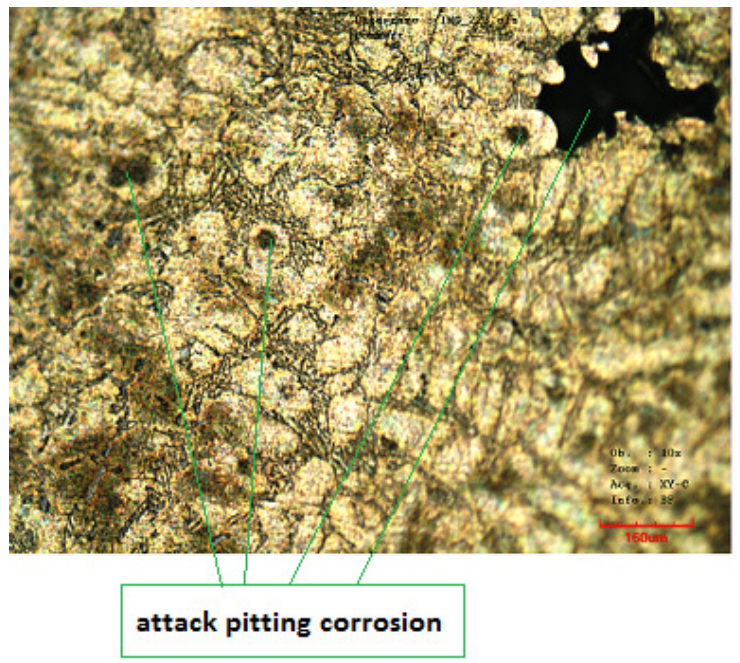

Fig. 4. Microstructure of corrosion attack of alloy AlSi7Mg0.3 with $0.1 \%$ Ca. The structure is composed of grains of solid solution $\alpha+\mathrm{Si}$ (modified $\mathrm{Si}$ to discolour to blue). The structure is porous, attacked pitting corrosion. Colour etching solution $\mathrm{KMnO4+NaOH} \mathrm{(100x} \mathrm{magnification)}$

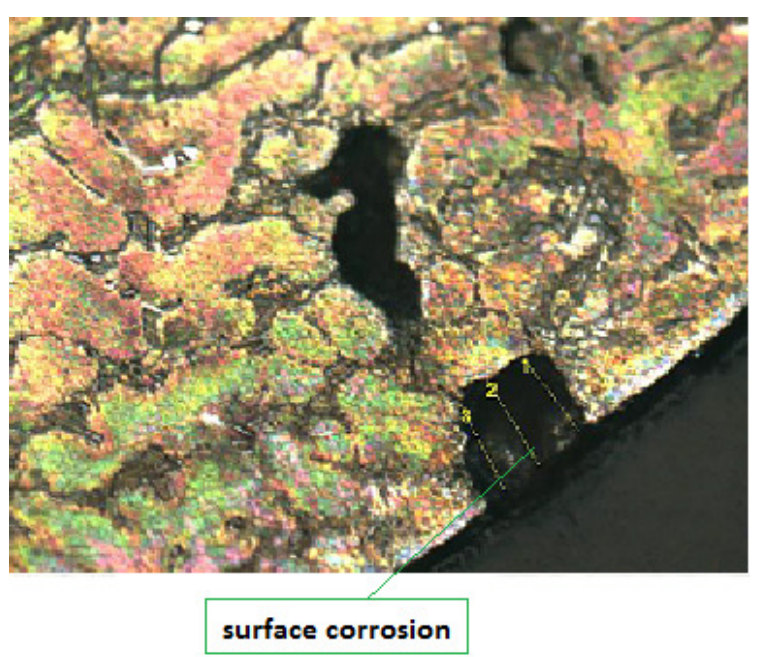

Fig. 5. Microstructure of corrosion attack of alloy AlSi7Mg0.3 with $0.1 \%$ Ca. The structure is composed of grains of solid solution $\alpha$ and eutectic $\alpha+\mathrm{Si}$. The structure is evident surface corrosion penetrating into the depth of the material with a size of approximately $120 \mu \mathrm{m}$. Colour etching solution $\mathrm{KMnO4+NaOH} \mathrm{(100x}$ magnification)

\section{Default alloy AISi7Mg0.3 with $0.5 \%$ Ca}

Other significant changes in the structure occurred by the addition of $0.5 \% \mathrm{Ca}$. This type of sampling leads to various manifestations, which can result in increased calcium content. There is clumping of porous places due to the increasing gassing, to more frequent occurrence of thickened particles of eutectic silicon on the edge of the dendrites, which were identified, such as a new intermetallic phase of the type CaAl6Si4, which manifest themselves as fine needles or coarse angular particles of irregular geometric shape. In this type of alloy pitting appeared again visibly reduced (Fig. 6). Corrosion occurs less in comparison with the previous cases, it attacks mainly the places where there is the solid solution $\alpha$, as in the previous cases. The size of the spots of surface corrosion attack also decreases to approximately $15 \mu \mathrm{m}$. In Fig. 7 with 100x magnification is shown a place of challenged pitting corrosion, even in this type of corrosion attack the change in a positive way is visible, where the decline of the surface corrosion attack is manifested, the corrosion progresses to a depth of a few tens of $\mu \mathrm{m}$.

\section{Default alloy AlSi7Mg0.3 with $1 \% \mathrm{Ca}$}

The last cast was ready with yet another increase in the calcium content and to a value of $1 \% \mathrm{Ca}$. The calcium content is visible making other new intermetallic phases probably different, mainly in size. Again it causes local occurrence of thickened particles of eutectic silicon and also crowding of porous places as in the previous case. The structure is again visible attack surface pitting corrosion (Fig. 8), the incidence appears more often than in the calcium content of $0.5 \% \mathrm{Ca}$. Surface corrosion penetrates into the depth of the material (Fig. 9) and is more conspicuous. It goes deeper to microstructures up to several hundreds of $\mu \mathrm{m}$, the average depth of corrosion attack is around $350 \mu \mathrm{m}$. 


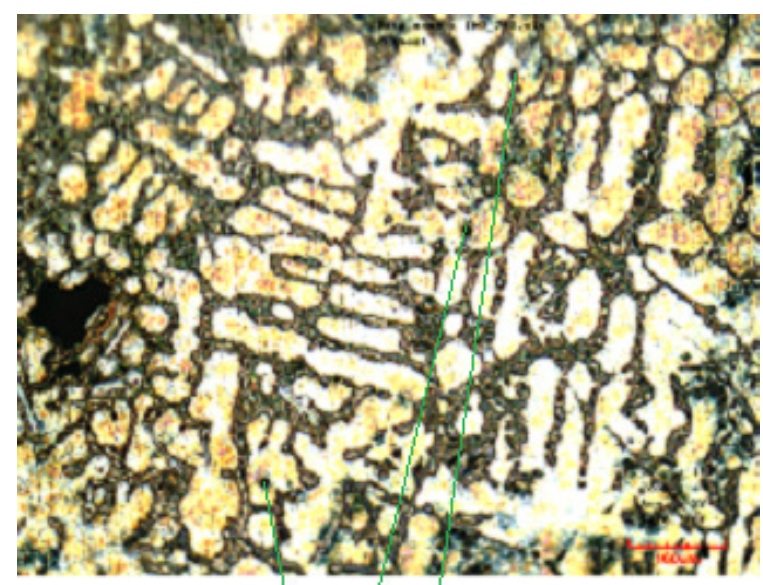

attack pitting corrosion

Fig. 6. Microstructure of corrosion attack of alloy AlSi7Mg0.3 with $0.5 \%$ Ca. The structure is composed of grains of solid solution $\alpha$ and eutectic $\alpha+$ Si. Noticeable are porous places, and in the structure thickened particles of silicon in the shape of needles and angular particles will appear more fully. The structure is attacked by pitting corrosion. Colour etching solution $\mathrm{KMnO4+NaOH}$ (100x magnification)

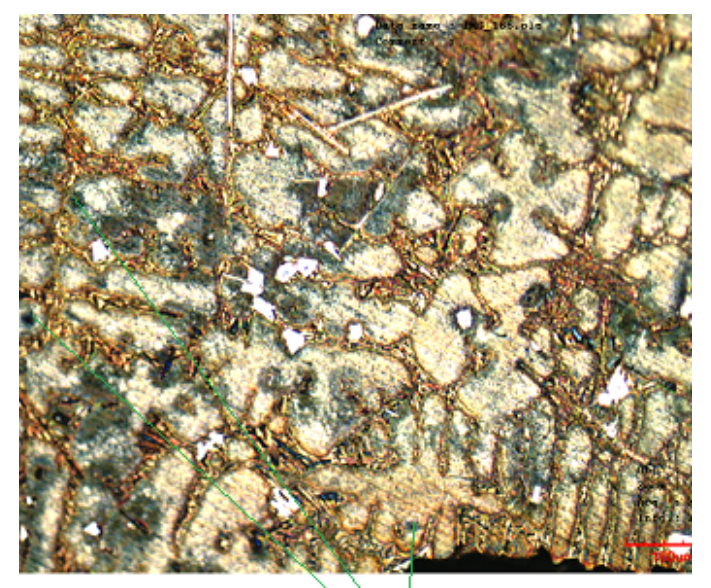

attack pitting corrosion

Fig. 8. Microstructure of corrosion attack of alloy AlSi7Mg0.3 with $1 \%$ Ca. The structure is composed of grains of solid solution $\alpha$, eutectic $\alpha+\mathrm{Si}$ and thickened particles of silicon in the shape of needles and angular particles. Noticeable are the porous space and assault pitting corrosion. Colour etching solution $\mathrm{KMnO4+NaOH}$ (100x magnification)

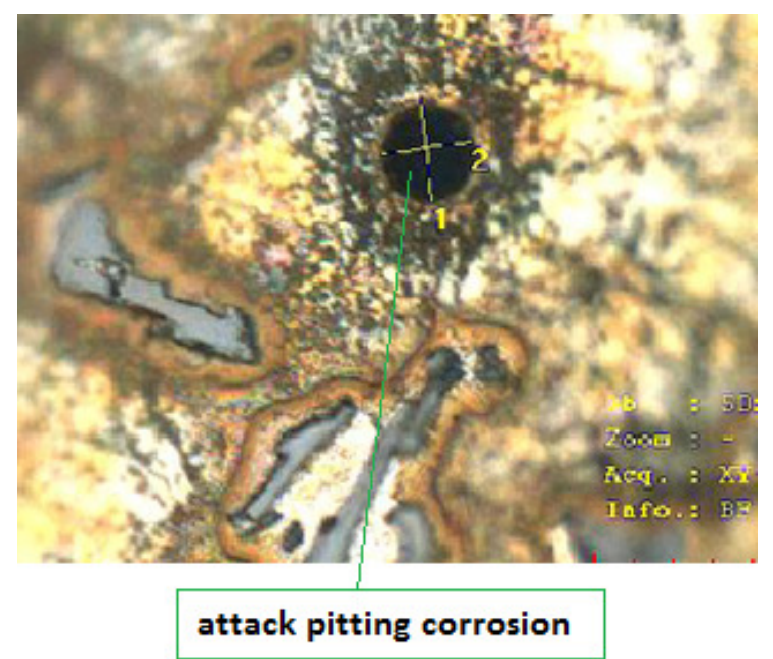

Fig. 7. Microstructure of corrosion attack of alloy AlSi7Mg0.3 with $0.5 \%$ Ca. The structure is composed of grains of solid solution $\alpha$ and eutectic $\alpha+\mathrm{Si}$, and thickened particles of silicon in the shape of needles and angular particles. The structure is evident surface by pitting corrosion. Colour etching solution $\mathrm{KMnO4+NaOH}(500 x$ magnification)

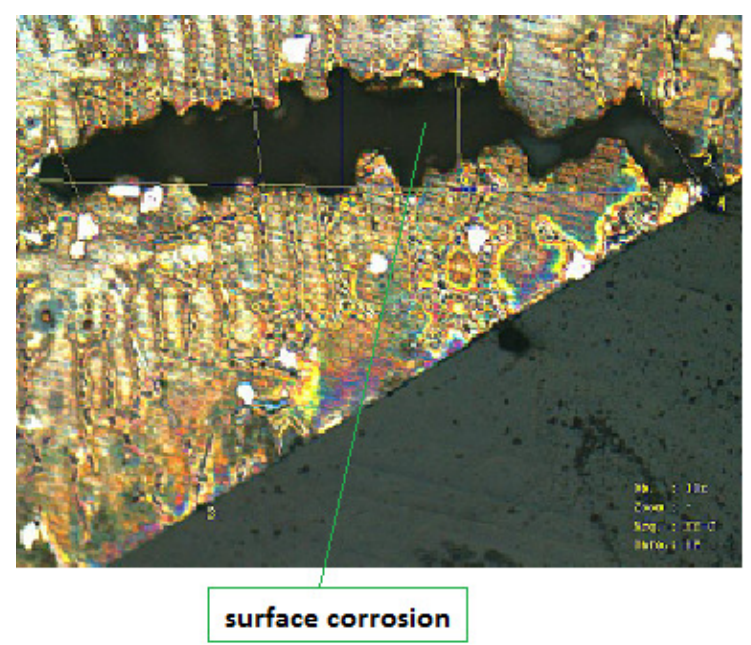

Fig. 9. Microstructure of corrosion attack of alloy AlSi7Mg0.3 with $1 \%$ Ca. The structure is composed of grains of solid solution $\alpha$, eutectic $\alpha+\mathrm{Si}$ and thickened particles of silicon in the shape of needles and angular particles. The structure is evident surface corrosion penetrating clearly into the depth of the material. Colour etching solution $\mathrm{KMnO4+NaOH}$ (100x magnification) 


\section{Conclusion}

The microstructure of the analyzed sample corrosion attack showed at all casts a certain degree of surface corrosion attack. One of the implied reasons is the used technology of gravity casting, which has affected the formation and the amount of porosity castings, another reason was the calcium content in the castings. In the case of the first two samples, the starting alloy with no added amount of $0 \% \mathrm{Ca}$, and the default alloy with added amounts of $0.1 \% \mathrm{Ca}$ there is a clear gradual increase in the volume of surface corrosion attack pitting corrosion. Castings without the added amount of calcium reach the size of corrosion attack of several tens of $\mu \mathrm{m}$. Castings with a content of calcium of $0.1 \%$ reach a size of corrosion attack of the higher values around $120 \mu \mathrm{m}$. In the cast with an added amount of $0.5 \% \mathrm{Ca}$ it is clear that pitting corrosion is in the number of infected sites smaller and these places are interested in a smaller areal proportion in the microstructure of the casting. It is clear therefore that the quality of the casting in terms of corrosion attack is in the case of a content of $0.5 \% \mathrm{Ca}$ better than the previous or in the case of the following. With the last of the castings with an added amount of calcium of 1 $\mathrm{mm} . \% \mathrm{Ca}$ it is seen that once again there is an increase in surface corrosion attack and up to several hundred $\mu \mathrm{m}$.

The analysis showed a visible effect of calcium on the structure. There is a change in the morphology of the eutectic, by changing the shape of the excluded silicon in the eutectic and to the emergence of different types of intermetallic with compounds. From the foregoing, it is possible to conclude that the colour metallographic is possible to be used in aluminium alloys in different directions, when etching of the samples occurs on the surface to induce optical contrast. This is due to the way some parts of the surface of the sample after the procedure reflect the light. This way we can obtain information of diverse nature, acquire new knowledge about the structure, or expand the already acquired knowledge in comparison with black and white images.

\section{References}

1. Michna Š., et.al. Encyklopedie hliníku (Encyclopedia of Aluminum), Adin 2005, ISBN 80-8904188-4. (In Czech).

2. Bolibruchová D.,Tillová E. Zlievarenské zliatiny Al-Si, ŽU v Žiline - EDIS, 2005, ISBN 80-8070-485-6. (In Czech).

3. Michna Š., Střihavková E. Legování hliníkových slitin vápníkem (Aluminum alloying with calcium), Strojírenská Technologie, 2010, roč. 15, č.2, pp. 20-23. (In Czech).

4. Mondolfo L.F. Aluminium Alloys, Structure and Properties, Butterworths, London 1979.

5. Kuchař L., Drápala J. Binární systémy hliník - přímesy a jejich význam pro metalurgii (Aluminum binary systems - additions and their importance for metallurgy), 2003 Delta Print Děčín, ISBN 80-239-1469-3. (In Czech).

6. Michna Š. Strukturální analýza a vlastnosti předslitiny AlCa10 (Structural analysis and properties of AlCa10 alloy), Strojírenská technologie, 2010, pp. 175-176. (In Czech). 